\title{
Analysis into the Universal Emotion of Human Beings to Develop a Humanities based Therapeutic Program
}

\author{
Arma Park', Moon-Joon Kim¹, Hyeon-Dong Song ${ }^{2}$, Sang-Yoon Ahn³, ChongHyung Lee ${ }^{3}$ and \\ Kwang-Hwan Kim ${ }^{3 *}$ \\ 'Department of General Art Education, College of General Education, Konyang University, Korea; \\ parkarma@konyang.ac.kr,kmj@konyang.ac.kr \\ 2Department of Global Hotel \& Tourism, College of Tax and Business Administration, Konyang University, Korea; \\ ritual@konyang.ac.kr \\ ${ }^{3}$ Department of Hospital Management, College of Medical Science, Konyang University, Korea; \\ greahn@konyang.ac.kr, chlee@konyang.ac.kr, kkh@konyang.ac.kr
}

\begin{abstract}
Background/Objectives: Understanding the universal feelings of humans and its association words is expected to provide fundamental resources for the diagnosis and prescription of target patients, which is essential in the humanities therapy. Methods/Statistical Analysis: A questionnaire survey was conducted for the study method. The general characteristics were analyzed for frequency using the statistic program R, and a multiple response analysis was conducted for the questions about association words. Perception of Koreans about love stays at a community level such as family rather than at an individual level. Findings: In the case of 'Happiness'-associated words Koreans put more importance on the spiritual satisfaction than the actual behavior or objects in terms of their value in happiness. Perception of Koreans about sadness is relationship-centered and they suffer an emotional injury when those relationships are cut off or split up. Koreans consider death their fate whereas they understand it negative causing fear, terror and loss rather than accept it as a part of life. Improvements: This study finding are expected to be used as effective resources to develop a therapeutic program relevant to mental disorders as it was based on the empirical analysis into the universal emotion such as the values of happiness and death of ordinary people.
\end{abstract}

Keywords: Emotion Analysis, Death Education, Therapeutic Program, Word Association

\section{Introduction}

As humans are maintaining vitality with its body combined with its mind, both mental and physical factors need to be considered when treating diseases. Especially, as death is the last step in a human being's growth and development, it is necessary to better understand death and accept and prepare for it with a mature attitude ${ }^{1}$. All human beings to death are some of the philosophers and researchers in the subject of fear and fundamental fear explains the fear of death, but was trying to understand, death is still remaining in the fundamental suffering of human beings ${ }^{2}$.
As the subject of death is human beings, death should be understood not only in biological and medical perspectives, but also in human-centered perspective that extinction of a life and severance of social relations $s^{3,4}$. However, not only the theoretical knowledge and practical education on death is insufficient, there is in reality is missing also very empirical studies to this ${ }^{5}$. In addition, in the death associated with domestic and international research, research methods and subject related to consciousness and attitudes of death is very diverse, in the case of our country, in most cases that was used as the contents and concepts of the questionnaire, which was applied to Westerners, is 
insufficient understanding of the deeper content of the values of the death ${ }^{5-8}$.

Looking at the medical humanities field which emphasizes that "a humanitarian doctor is medical staff equipped with emotional sensitivity and sympathy with patients" through literature and art, it is evident that an understanding of human beings is essential as well as scientific knowledge. Therefore, emotional and psychological factors should be more considered than biological factors in order to treat mental issues of the modern people such as fear of solitude and death, mental disorders, and trauma caused by a psychological shock following an accident.

We came to a decision that physical and mental problems of humans cannot be separated being closely correlated, and especially when diagnosing and treating a mental problem, universal emotions like triumphs and tragedies have to be prioritized. In particular, how ordinary people perceive so called 'positive values' and 'negative values' was to be investigated by selecting emotions such as 'love', 'happiness', and 'sadness' and analyzing what association processes are stimulated by these words ${ }^{10}$. The findings of this research were to be utilized as baseline resources to develop a therapeutic program based on the humanities.

The humanities therapy including an art therapy "has settled in major European nations as 'alternative medicine or a supplementary medical trial', and a traditional humanistic and artistic methodology is being applied especially, to overcome mental and emotional disabilities"11. The Meaning of 'healing' in the humanities which is spoken in literature, history, philosophy has to prevent and heal the individual problems with a mental, emotional, and social problems ${ }^{12}$. The detailed areas of the humanities therapy include a reading therapy, a writing therapy and an art and music therapy as well as a conventional drama therapy ${ }^{13,14}$.

It was decided essential to investigate how people perceive 'positive values' and 'negative values' for an effective invention and application of a humanities therapeutic program. Understanding the universal feelings of humans and its association words is expected to provide fundamental resources for the diagnosis and prescription of target patients, which is essential in the humanities therapy. Also, this kind of resource is supposed to be useful in developing an individual therapeutic program such as a writing therapy, a drama therapy, and an art and music therapy.

\section{Study Method}

\subsection{Study Participants}

Study participants were selected from the 150 people who attended a local government event. Five of them whose answers were unreliable were excluded from the analysis.

\subsection{Study Method}

A questionnaire survey was conducted for the study method. The questionnaire was comprised of eight items such as gender, age, education, job, marriage status, family cohabitation, religion, and health status, and the questions about association words included four items like 'love', 'happiness', 'sadness', and 'death'. In a question about association words, choice alternatives were composed of the responses from the short-answer pilot test which was conducted prior to the survey. The general characteristics were analyzed for frequency using the statistic program $\mathrm{R}$, and a multiple response analysis was conducted for the questions about association words.

\section{Study Results}

\subsection{General Characteristics of Participants}

The general characteristics of the participants were as follows. The total number of 145 people were comprised of 61 males (42.1\%) and 84 females (57.9\%). The age distribution was even with 41 people as the most (28.3\%) aged between 30 and 44, 40 people (27.6\%) aged between 15 and $29,22.7 \%$ aged 14 and below, and $21.4 \%$ aged 45 and over.

In the educational background distribution, 95 people were high school graduates as the highest (65.5\%) followed by 37 university graduates (25.5\%), and 13 postgraduate school graduates $(9.0 \%)$. Looking at the participants' job distribution, a student had the highest distribution with 73 people followed by 46 office workers (31.7\%) and 20 housewives (13.8\%).

A marriage status showed no significant difference between singles and those married with 76(52.4\%) and $69(47.6 \%)$ respectively. As for the family cohabitation, 127 people (87.6\%) responded to be 'living with family' while 18 people (12.4\%) answered 'living on their own'. 
In a religion item, 84 people $(57.9 \%)$ had no religion, whereas those with religion took up $42.1 \%$.

For the health status, 'healthy' and 'very healthy' were responded by 75 people (51.7\%) and 59(40.7\%) respectively, which indicated that $92.4 \%$ of the participants were in a healthy status Table 1.

Table 1. General characteristics of participants

Unit:N(\%)

\begin{tabular}{|c|c|c|}
\hline \multicolumn{2}{|c|}{ Items } & \multirow{2}{*}{ Total } \\
\hline Gender & & \\
\hline & Male & $61(42.1)$ \\
\hline & Female & $84(57.9)$ \\
\hline \multicolumn{3}{|l|}{ Age } \\
\hline & $\begin{array}{l}14 \text { years old and } \\
\text { below }\end{array}$ & $33(22.7)$ \\
\hline & $\begin{array}{l}\text { Between } 15 \text { and } \\
29\end{array}$ & $40(27.6)$ \\
\hline & $\begin{array}{l}\text { Between } 30 \text { and } \\
44\end{array}$ & $41(28.3)$ \\
\hline & $\begin{array}{l}45 \text { years old and } \\
\text { over }\end{array}$ & $31(21.4)$ \\
\hline \multicolumn{3}{|c|}{ Education } \\
\hline & $\begin{array}{l}\text { Highschool and } \\
\text { below }\end{array}$ & $95(65.5)$ \\
\hline & University & $37(25.5)$ \\
\hline & $\begin{array}{l}\text { Postgraduate } \\
\text { School }\end{array}$ & $13(9.0)$ \\
\hline \multicolumn{3}{|c|}{ 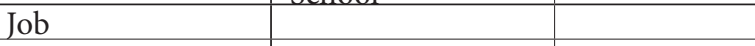 } \\
\hline & $\begin{array}{l}\text { Office/Service } \\
\text { work }\end{array}$ & $46(31.7)$ \\
\hline & Blue Color work & $5(3.4)$ \\
\hline & Student & $73(50.3)$ \\
\hline & Housewife & $20(13.8)$ \\
\hline & Others & $1(.7)$ \\
\hline \multicolumn{3}{|c|}{ Marriage } \\
\hline & Single & $76(52.4)$ \\
\hline & Married & $69(47.6)$ \\
\hline \multicolumn{3}{|c|}{$\begin{array}{l}\text { Cohabitation with } \\
\text { Family }\end{array}$} \\
\hline & Living Alone & $18(12.4)$ \\
\hline & $\begin{array}{l}\text { Living with } \\
\text { Family }\end{array}$ & $127(87.6)$ \\
\hline \multicolumn{3}{|l|}{ Religion } \\
\hline & Unreligious & $84(57.9)$ \\
\hline & Religious & $61(42.1)$ \\
\hline \multicolumn{3}{|c|}{ Health Status } \\
\hline & Very Healthy & $59(40.7)$ \\
\hline & Healthy & $75(51.7)$ \\
\hline & Unhealthy & $8(5.5)$ \\
\hline & Very Unhealthy & $3(2.1)$ \\
\hline \multicolumn{2}{|c|}{ Total } & $145(100.0)$ \\
\hline
\end{tabular}

\subsection{Association words of 'Love'}

As for the question asking what comes into mind when looking at a word 'Love', the results were shown as below. 'Family' was the most answered by 95 people (65.5\%) followed by 'Date' by 56(38.6\%), 'Heart' by $45(31.0 \%)$, 'Parent' by 39(26.9\%), 'Excitement' by 38(26.2\%), Mind by $36(24.8 \%)$, and 'Marriage' by $35(24.1 \%)$. This result suggests that most of the love-associated words were the ones with positive feelings Table 2 .

Table 2. Association words of 'Love'

Unit:N(\%)

\begin{tabular}{|l|c|}
\hline Items & Total \\
\hline Association words of Love & \\
\hline Family & $95(65.5)$ \\
\hline Date & $56(38.6)$ \\
\hline Heart & $45(31.0)$ \\
\hline Parent & $39(26.9)$ \\
\hline Excitement & $38(26.2)$ \\
\hline Mind & $36(24.8)$ \\
\hline Marriage & $35(24.1)$ \\
\hline Couple & $32(22.1)$ \\
\hline Friend of the Opposite Sex & $25(17.2)$ \\
\hline Romance & $25(17.2)$ \\
\hline Affirmation & $23(15.9)$ \\
\hline Hug & $21(14.5)$ \\
\hline Heart (Cardiac) & $20(13.8)$ \\
\hline Sincerity & $20(13.8)$ \\
\hline Thrill & $20(13.8)$ \\
\hline Sacrifice & $18(12.4)$ \\
\hline Pet & $16(11.0)$ \\
\hline Flower & $16(11.0)$ \\
\hline Blessing & $14(9.7)$ \\
\hline Fantasy & $9(6.2)$ \\
\hline Pink & $8(5.5)$ \\
\hline Overwhelming & $5(3.4)$ \\
\hline Nickname & $1(.7)$ \\
\hline Illusion & \\
\hline
\end{tabular}

\subsection{Association Words of 'Happiness'}

The result was as follows for the question asking about the association words of 'Happiness'. 'Brightness' was the most responded by 76(52.4\%) out of all participants. It was followed by 'Pleasure' with 69 people (47.6\%), 'Family' with 61(42.1\%), 'Laughter' with 58(40.0\%), 'Warmth' with 52(35.9\%), 'Stability' with 45(31.0\%), 'Enjoyment' with 44(30.3\%), 'Comfort' with 43(29.7\%), and 'Abundance' with $41(28.3 \%)$ Table 3. 
Table 3. Association words of 'Happiness'

Unit:N(\%)

\begin{tabular}{|l|c|}
\hline Items & Total \\
\hline Association words of Happiness & \\
\hline Brightness & $76(52.4)$ \\
\hline Pleasure & $69(47.6)$ \\
\hline Family & $61(42.1)$ \\
\hline Laughter & $58(40.0)$ \\
\hline Warmth & $52(35.9)$ \\
\hline Stability & $45(31.0)$ \\
\hline Enjoyment & $44(30.3)$ \\
\hline Comfort & $43(29.7)$ \\
\hline Abundance & $41(28.3)$ \\
\hline Luck & $36(24.8)$ \\
\hline Friend & $35(24.1)$ \\
\hline Freedom & $33(22.8)$ \\
\hline Rest/Holiday & $31(21.4)$ \\
\hline Satisfaction & $27(18.6)$ \\
\hline Beauty & $23(15.9)$ \\
\hline Food & $22(15.2)$ \\
\hline Sunshine & $21(14.5)$ \\
\hline Leisure Life & $16(11.0)$ \\
\hline Song & $14(9.7)$ \\
\hline Pet & $12(8.3)$ \\
\hline Sky & $11(7.6)$ \\
\hline Trivial things & $10(6.9)$ \\
\hline Storybook & $2(1.4)$ \\
\hline &
\end{tabular}

\subsection{Association Words of 'Sadness'}

The association words of 'Sadness' were responded by 93 people (64.1\%) as 'Tear' followed by 'Gloominess' by 71(49.0\%), Farewell by 67(46.2\%), 'Loneliness/Solitude' by 63(43.4\%), 'Pain' by 60(41.2\%), 'Hardship' by 43(29.7\%), 'Death' by $42(29.0 \%)$, 'Accident' by $2(20.0 \%)$, and 'Loss' and 'Coldness' by $24(16.6 \%)$ respectively Table 4.

\subsection{Association Words of 'Death'}

The association words of 'Death' were answered by 69 people (47.6\%) as 'Sadness' followed by 'What will happen sometime' by $57(39.3 \%)$, 'Farewell' by $55(37.9 \%)$, 'Funeral' by $51(35.2 \%)$, 'Darkness/ Shadow' by $41(28.3 \%)$, 'Fear' by $35(24.1 \%)$, 'Black' by $33(22.8 \%)$, 'Tear' by $32(22.1 \%)$, 'End' by 31(21.4\%), 'Cemetery' by 30(20.7\%), 'Disappearance' by 28(19.3\%)respectively Table 5.

\subsection{Top Five Love and Sadness Associated Words}

The top five 'Love'-associated words were 'Tear', 'Gloominess', 'Farewell', 'Loneliness' and 'Pain'. The result which analyzed the 'Happiness'-associated words by people who answered 'Family' could be presented as in Figure 1. Unlike the analysis for the whole participants in Table 2, 'Pleasure' was the most answered by 51 people Figure 1. According to the result which looked at the 'Death'associated words by 93 people who answered 'Tear', the most answered among the five 'Sadness'-associated words, 'Sadness' was the most answered by 53 people. It was followed by 'What will happen sometime' and 'Farewell' Figure 2. Both Figure 1 and Figure 2 shows no significant difference between the upper items when compared to the total frequency.

The relationship diagrams which were drawn to examine the correlation between association words of each item are shown as follows. Above all, 'Love' and 'Happiness' had in common 'Family' and 'Pet' as its associated words regardless of the frequency of each association word Figure 3. 'Sadness' and 'Death' were found to have in common 'Tear' and 'Farewell' as its association words. Also, 'Sadness' and 'Death' were included in each other's association words Figure 4.

Table 4. Association words of 'Sadness'

Unit:N(\%)

\begin{tabular}{|l|c|}
\hline Items & Total \\
\hline Association words of Sadness & \\
\hline Tear & $93(64.1)$ \\
\hline Gloominess & $71(49.0)$ \\
\hline Farewell & $67(46.2)$ \\
\hline Loneliness/Solitude & $63(43.4)$ \\
\hline Pain & $60(41.2)$ \\
\hline Hardship & $43(29.7)$ \\
\hline Death & $42(29.0)$ \\
\hline Accident & $29(20.0)$ \\
\hline Loss & $24(16.6)$ \\
\hline Coldness & $24(16.6)$ \\
\hline Mournng & $22(15.2)$ \\
\hline Poverty & $17(11.7)$ \\
\hline Violence & $14(9.7)$ \\
\hline Miserableness & $14(9.7)$ \\
\hline Cloudiness & $8(5.5)$ \\
\hline Time & $7(4.8)$ \\
\hline Alcohol & $6(4.1)$ \\
\hline Africa & $6(4.1)$ \\
\hline Grandparents & $3(2.1)$ \\
\hline Blue & $1(.7)$ \\
\hline
\end{tabular}


Table 5. Association words of 'Death'

Unit:N(\%)

\begin{tabular}{|l|c|}
\hline Items & Total \\
\hline Association words of Death & $69(47.6)$ \\
\hline Sadness & $57(39.3)$ \\
\hline What will happen some time & $55(37.9)$ \\
\hline Farewell & $51(35.2)$ \\
\hline Funeral & $41(28.3)$ \\
\hline Darkness/Shadow & $35(24.1)$ \\
\hline Fear & $33(22.8)$ \\
\hline Black & $32(22.1)$ \\
\hline Tear & $31(21.4)$ \\
\hline End & $30(20.7)$ \\
\hline Cemetery & $28(19.3)$ \\
\hline disappearance & $25(17.2)$ \\
\hline Longing & $22(15.2)$ \\
\hline Portrait of the deceased & $19(13.1)$ \\
\hline Accident & $19(13.1)$ \\
\hline Regret & $19(13.1)$ \\
\hline Heaven & $17(11.7)$ \\
\hline Coffin & $15(10.3)$ \\
\hline Ghost & $10(6.9)$ \\
\hline Rest & $8(5.5)$ \\
\hline Blood & $7(4.8)$ \\
\hline White & $5(3.4)$ \\
\hline Birth & \\
\hline
\end{tabular}

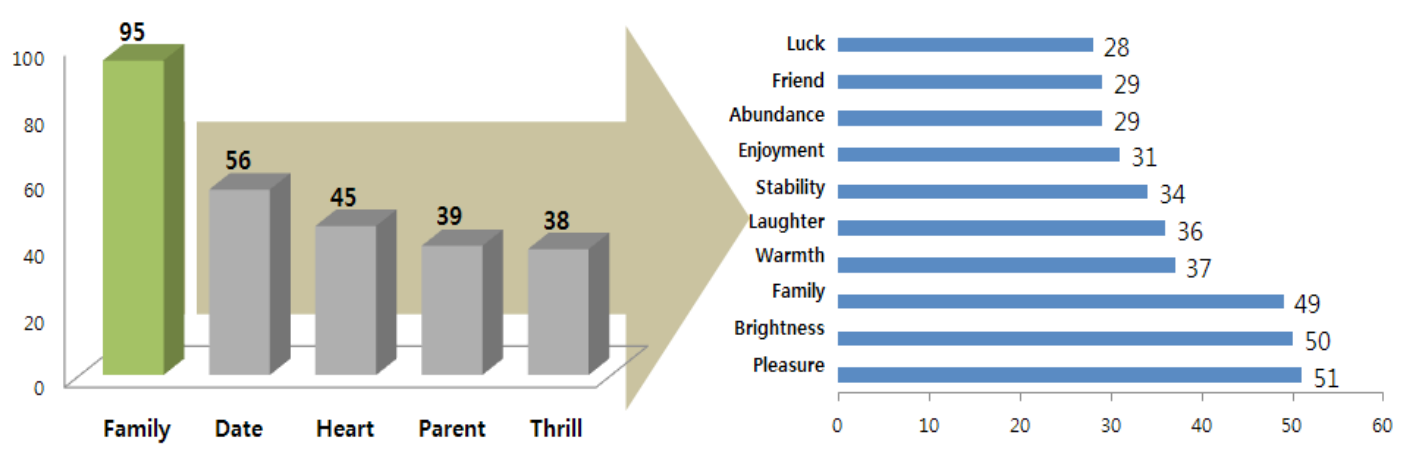

Figure 1. Top five love-associated words and Happiness-associated words by people who answered 'Family'.

\section{Conclusion and Discussion}

All human beings eventually die, but most people consider death as something that has nothing to do with themselves ${ }^{15}$.We investigated association words of the universal human feelings such as 'Love,, 'Happiness', 'Sadness' and 'Death' through a questionnaire survey for ordinary people. This investigation had its purpose in developing a humanities based therapeutic program rather than just looking at the resulting association words. Particularly, it was decided that a good understanding of the universal human emotion should be prioritized to develop a thera- 


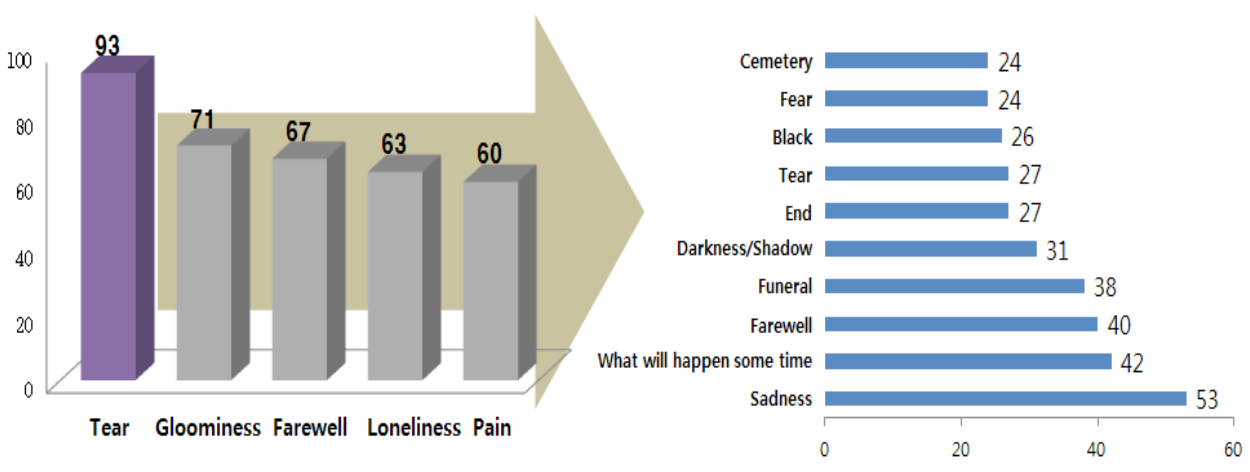

Figure 2. Top five Sadness-associated words and Death-associated words by people who answered 'Tear'.

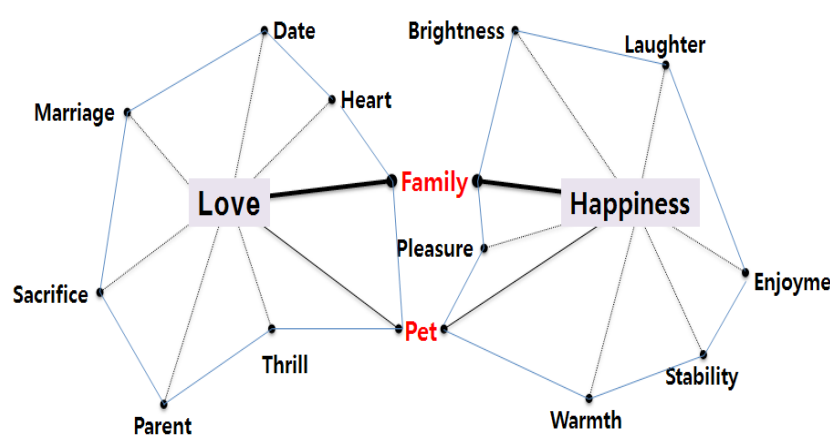

Figure 3. Relationship Diagram between 'Love'-associated words and 'Happiness'-associated words.

peutic program relevant to mental issues that human beings can face. The words such as 'Sadness' and 'Death' explained the situations experienced by people with mental disorders in that they present human feelings like unrest, fear, terror, bitterness, and regret. On the other hand, through an investigation of positive, hopeful and mentally comforting words such as 'Love' and 'Happiness', it was identified where humans try to reach out of the situations inflicting scar and pain including 'Sadness' and 'Death'.

As for the 'Love'-associated words, 'Family', 'Parent', and 'Marriage' were 65\%, 26.9\% and 24.1\% respectively. This suggests that a perception of Koreans about love is hard to get out of their values formed around parents and spouses. On the other hand, 'Romance,' 'Thrill' and 'Pink' were shown relatively low at $17.2 \%, 13.8 \%$ and 5.5\% respectively. It can be assumed from this result that a perception of Koreans about love stays at a community level

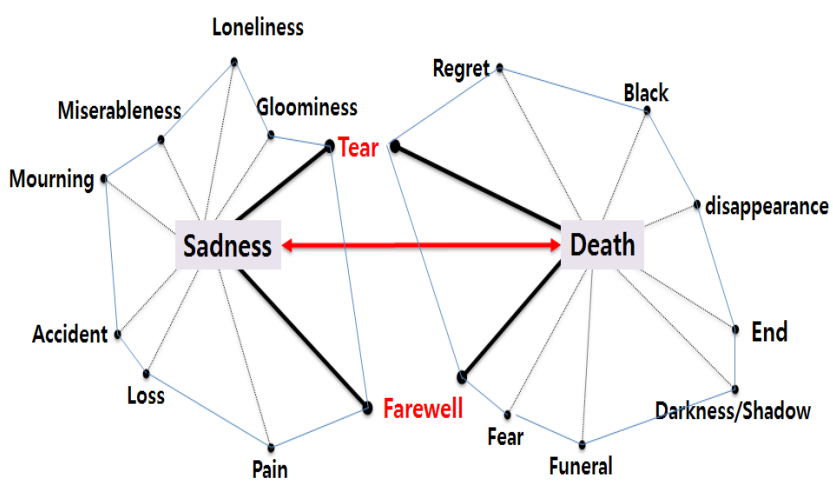

Figure 4. Relationship Diagram between 'Sadness'associated words and 'Death'-associated words.

such as family rather than at an individual level. In the case of 'Happiness'-associated words, 'Brightness', Family' and 'Warmth' took up 52.4\%, $42.1 \%$ and $35.9 \%$ respectively. This suggests that a perception of Koreans about happiness remains more at a spiritual and abstract level than material and substantive matters, and pursues a family-directed value of happiness just as in the case of love. On the other hand, 'Rest/Holiday, 'Food', and 'Pet' stayed at $21.4 \%, 15.2 \%$ and $8.3 \%$ respectively. It can be supposed by this result that Koreans put more importance on the spiritual satisfaction than the actual behavior or objects in terms of their value in happiness.

As for the 'Sadness'-associated words, 'Farewell', 'Death' and 'Loss' took up 46.2\%, 29.0\% and 16.6\% respectively. This result shows that a perception of Koreans about sadness is relationship-centered and they suffer an emotional injury when those relationships are cut off or split up. It may not be irrelevant to their family- 
focused values. Looking at the 'Death'-associated words, 'What will happen sometime', 'Farewell' and 'Fear' took up $39.3 \%, 37.9 \%$ and $24.1 \%$ respectively. This outcome indicates that Koreans consider death their fate whereas they understand it negative causing fear, terror and loss rather than accept it as a part of life. One of the reasons is because death brings a disconnection and disintegration of the relationship and family which is one of the most important values in the life of Koreans.

Our study has a limit of not having the enough number of participants and not showing a difference in the perception of each participant. Therefore, a further study needs to solve a task that it has to have an extensive number of participants and perform a comparison analysis into the difference of perception for each participant. Nevertheless, these study findings are expected to be used as effective resources to develop a therapeutic program relevant to mental disorders as it was based on the empirical analysis into the universal emotion such as the values of happiness and death of ordinary people. Eventually, a humanities based therapeutic program which will be developed in the future should reflect the values and perception of Koreans that are family-oriented and relationship-centered when considering the outcomes of this study.

\section{Acknowledgment}

This study was conducted in an accordance with the National Research Foundation of Korea (NRF) 2014S1A5B6035107.

\section{References}

1. Hyun EM. Effect of death education program for university students. Journal of the Korea Academia-Industrial Cooperation Society. 2014; 15(7):4220-28.

2. Jung BR. The meaning and direction of preparatory education of death. Kyungpook Journal of Nursing Science. 2006; 10:49-60.
3. Park A, Kim KH, Anh SY. An analysis of death education-related work duty on medical care providers using the DACUM method. International Journal of Applied Engineering Research. 2015 Aug; 10(13):33792-96.

4. Kim KH, Kim YH, Ahn SY, Lee CH, Lee MS, Kim MJ, Park A, Hwang HJ, Shim MS, Song HD. The Journal of targeted at the general public for the modeling of well-dying program development. 2014; 12(8):369-76.

5. Kramer BJ, Boelk AZ, Auer C. Family conflict at the end of life; lessons learned in a model program for vulnerable older adults. Journal of Palliative Medicine. 2006 Jun; 9(3):791-801.

6. Song HD. Death in contemporary Korea, in Relation to Thanatology and Religious Studies. Journal of Religion and Culture. 2008; 10:139-59.

7. Hwang HJ, Kim KH, Kim YH, Lee MS, Shim MS. Job analysis by DACUM method in the field of well dying education model development: focusing on the social worker. Journal Of Academia-Industrial Technology. 2015; 16(8):5501-07.

8. Oh JT, Kim CG. Effects of death education on attitude toward death and depression in older adults. Journal of The Korean Gerontological Society. 2009; 29(1):51-69.

9. Kang WS, Yim S-H, Harris I, Na H, Kim PM. Students' perspectives about the medical humanities curriculum at the Catholic University of Korea. International Journal of Medical Education. 2013; 4:207-13

10. Kalof L. Species matters: humane advocacy and cultural theory. International Journal of Applied Philosophy. 2008; 12(1):51-61.

11. Kim MS. Characteristics of the Korean's representation and understanding on happiness and good death. The Journal of Humanities Studies. 2011; 86:307-52.

12. Nobel J, Stuckey HL. The connection between art, healing, and public health. A Review of Current Literature. 2010 Feb; 100(2):254-63.

13. Berman RA. The return of humanistic reading: healing through reading. Citizen and Humanities; 2013 Jun .

14. Canby CA1, Bush TA. Humanities in gross anatomy project. Anatomical Sciences Education. 2010 Mar-Apr; 3(2):94-6.

15. Kassa H, Murugan R, Zewdu F, Hailu M, Woldeyohannes D. Assessment of knowledge, attitude and practice and associated factors towards palliative care among nurses working in selected hospitals. BMC Palliative Care. 2014; 13:1-6. 